\title{
TẠO ADENOVIRUS TÁI TỔ HợP MANG ĐOẠN GEN chIL-6
}

\author{
Vũ Thị Thu Huyền ${ }^{1, *}$, Lê Thị Hồng Minh ${ }^{1}$, Nguyễn Thị Kim Cúc ${ }^{1}$, \\ Vũ Thị Quyên ${ }^{1}$, Nguyễn Mai Anh ${ }^{1}$, Lê Thanh Hòa ${ }^{2}$, Phạm Việt Cường ${ }^{1}$ \\ ${ }^{1}$ Viện Hóa sinh biển, VAST, 18, Hoàng Quốc Việt, Cầu Giấy, Hà Nội \\ ${ }^{2}$ Viện Công nghệ sinh học, VAST, 18, Hoàng Quốc Việt, Cầu Giấy, Hà Nội \\ "Email: Huyenvuibt@gmail.com
}

Đến Tòa soạn: 3/6/2014; Chấp nhận đăng: 24/11/2015

\section{TÓM TẮT}

Sau nghiên cứu công bố năm 2013, chúng tôi đã tách dòng thành công đoạn gen interleukin 6 của gà Việt Nam $(c h I L-6)$. Với mục đích tạo adenovirus tái tổ hợp nhẳm tạo chế phẩm gây kích ứng miễn dịch cho gia cầm. Sau khi thu nhận đoạn gen từ mô lá lách gà, tách dòng bằng kỹ thuật RT-PCR, đoạn gen chIL-6 được chuyển vào vector con thoi pENTR3C. vector con thoi pENTR3C mang vùng gen attL1 và attL2 tương ứng với 2 vùng gen tạo điểm tương đồng trong vector đích, nhằm tạo ra plasmid tái tổ hợp pAd / CMV-V5-chIL6.

DNA của plasmid tái tổ hợp pAd/CMV/V5- DEST mang gen ChIL-6 được cắt mở vòng bằng enzym giới hạn $P a c I$. $P a c I$ sẽ cắt tại vị trí để chia thành 2 chuỗi lặp trái (LITR) và phải (RITR) bao bọc lấy phần DNA tái tổ hợp adenovirus và gen chIL-6 ở giữa. Cuối cùng để tạo ra adenovirus tái tổ hợp, pAd / CMV-V5-chIL6 được xâm nhiễm vào tế bào thận bào thai người HEK293A (human embryonic kidney cell) để bao gói và nhân lên lượng lớn adenovirus tái tổ hợp. Sự biểu hiện của ChIL-6 được quan sát sau 48 giờ - 72 giờ sau xâm nhiễm. Adenovirus và đoạn gen ChIL-6 được phát hiện trong các tế bào HEK293A bằng PCR Kháng nguyên ChIL-6 được xác định nhờ kháng thể Chúng tôi sử dụng một số kĩ thuật ELISA tóm bắt kháng nguyên, kiểm tra adenovirus tái tổ hợp mang gen ChIL6 khi đã thực sự được hình thành. Mật độ virus xác định được là $5 \times 10^{9} \mathrm{PFU} / \mathrm{ml}$ sau khi tinh sạch bằng kit tinh sạch adenovirus ibiPure ${ }^{\mathrm{TM}}$ adeno(Đức).

Tù khóa: adenovirus tái tổ hợp, ChIL-6, cytokine, HEK293A, pAd/CMV/V5-DEST, pENTR3C.

\section{MỞ ĐẦU}

Ngày nay, ngày càng nhiều các dịch bệnh gia cầm bùng phát, kiến cho các cơ quan chức năng và chủ trang trại xử lí không kịp thời, dẫn đến tổn thất nặng nề về kinh tế và làm lan rộng, cũng như biến chủng tăng tính nguy hiểm của nguồn bệnh. Vì vậy, việc đưa ra các liệu pháp nâng cao khả năng miễn dịch nhằm chống lại các nguồn bệnh và hỗ trợ chữa bệnh cho gia cầm là một hướng tích cực và được xem như một dạng "thực phẩm chức năng" cho gia cầm.

IL-6 là một cytokine có vai trò đặc biệt đối với quá trình đáp ứng miễn dịch, IL-6 là cytokine trực tiểp tác động lên lympho $\mathrm{B}$ để sản xuất kháng thể $[1,2,3]$. Như vậy, nếu lượng IL- 
6 được tăng cường từ ngoài vào, đặc biệt thông qua vector tái tổ hợp để nguồn cytokine được biểu hiện nhân lên và sử dụng tại chỗ trong cơ thể, thì vấn đề tăng về số lượng các tế bào có thẩm quyền miễn dịch (kể cả lympho $\mathrm{B}$ sản xuất kháng thể) và tăng về số lượng và chất lượng kháng thể (sau nhiễm bệnh hoặc sau vaccine) do IL-6 kích thích sẽ được cải thiện [2, 4].

Trong các hệ thống vector dẫn truyền gen kháng nguyên làm vaccine thế hệ mới, hệ thống vector virus được đặc biệt chú trọng nghiên cứu và sử dụng do virus có đặc tính thích ứng tế bào đa vật chủ thông qua hệ thống thụ thể Toll, vô hại với nhiều loài, nhân lên mạnh khi nuôi cấy trên tế bào phù hợp cho hàm lượng virus nhiều đề sản xuất vaccine (in vitro) $[2,5,6]$.

Cho tới nay, hầu hết các hạt vector cơ sở cấu trúc capsid dạng hoang dã, ngoài nhiệm vụ bảo vệ DNA virus, nó còn là phương tiện để gắn và đi vào bên trong tế bào đích. Tuy nhiên, hệ gen virus đã có những cải biến đáng kể. Những biến đổi này được thiết lập nhằm vô hiệu hóa sự phát triển của virus trong tế bào đích do đã loại trừ những chức năng đặc biệt của virus đối với sự điều hòa sao chép DNA và sự biểu hiện gen virus trong khi vẫn có thể phát triển trong tế bào đóng gói hoặc tế bào trợ giúp. Việc loại bỏ các trình tự như vậy tạo ra không gian trong hệ gen virus để DNA ngoại sinh vẫn cài vào được mà vẫn biểu hiện được các gen chuyển. Các adenovirus vector được dùng cho gen trị liệu chủ yếu là các vector thay thế E1, ở đó các gen chuyển được cài vào vùng E1 là vùng gen phiên mã sớm của hệ gen adenovirus. Ngoài phần còn lại của hệ gen virus, vector này còn giữ lại đầu '5' gần nhất của hệ gen virus bao gồm các đoạn lặp tận cùng đảo ngược bên trái (ITR) và tín hiệu đóng capsid, các trình tự cần cho sự đóng gói và những vùng tăng cường $\mathrm{E} 1$ gối nhau. Vì các sản phẩm gen $\mathrm{E} 1$ sẽ làm hoạt hóa liên tục các đơn vị phiên mã chính nên khi loại trừ các vùng này thì sự biểu hiện sớm và muộn của gen sẽ giảm đi rất nhiều và làm sự sao chép của virus suy yếu một cách nghiêm trọng $[5,6,7]$.

Với định hướng là đưa ra các biện pháp an toàn linh hoạt, phòng bệnh tại chỗ để nâng cao tính chống chịu trước nguồn bệnh của gia cầm, trong nghiên cứu này, chúng tôi tạo adenovirus HAd serotype 5 (HAd5) tái tổ hợp mang đoạn gen hoạt tính cytokine chIL-6 nhằm tạo chế phẩm gây kích ứng miễn dịch cho gia cầm.

\section{NGUYÊN VẬT LIỆU VÀ PHƯƠNG PHÁP NGHIÊN CÚU}

\subsection{Nguyên vật liệu}

Plasmid $p C R 2.1 /$ chIL-6 đã được tách dòng từ lá lách gà Việt Nam tại phòng Công nghệ Sinh học - Viện Hóa Sinh Biển .

Vector con thoi $p E N T R 3 C$. Vector adenovirus $p A d / C M V-V 5-D E S T$. Tế bào HEK293A của hãng Invitrogen.

Kit chicken IL-6 ELISA (Cusabio-USA).

Các hóa chất sinh phẩm cần thiết khác của phòng thí nghiệm sinh học phân tử và phòng nuôi cấy tế bào động vật. Trang thiết bị máy móc cần thiết cho phòng thí nghiệm sinh học phân tử và phòng thí nghiệm tế bào động vật (máy li tâm văng, kính hiển vi soi ngược, box cấy class II, tủ ấm $\mathrm{CO}_{2} \ldots$ ).

\subsection{Phương pháp nghiên cứu}

Các kĩ thuật tách PCR, tinh sạch DNA, điện di DNA, điện di Protein, tách plasmid, cắt bằng enzyme cắt giới hạn RE, nuôi cấy tế bào động vật, ELISA, quy trình tạo adenovirus tái tổ 
hợp được thực hiện dựa trên hướng dẫn của nhà cung cấp khung adenovirus $p A d / C M V-V 5-D E S T$ [8]. Các kiến thức về tin sinh học đã được sử dụng trong nghiên cứu này.

Tạo plasmid con thoi chúa đoạn gen chIL-6: Để chuyển đoạn gen thu nhận được vào vector con thoi $p E N T R 3 C$, là vector trung gian chuyển gen vào adenovirus vector, chúng tôi thiết kế cặp mồi mới có gắn 2 enzyme cắt giới hạn $X h o \mathrm{I}, K p n \mathrm{I}$ và trình tự kozak cần thiết khi chuyển vào vector $p E N T R 3 C$.

Sản phẩm PCR (hộp gen RE-Kozak-ChILO) sau khi được gắn vào vector tách dòng pUC57 (genscirpt), biến nạp vào $E$. Coli $\mathrm{DH} 5 \alpha$, tách plasmid bằng kit tách plasmid của Fermentas. Cắt pUC57/ChIL6 và plasmid trung gian bằng các enzyme giới hạn $K p n \mathrm{I}$ và XhoI, tinh sạch, gắn sản phẩm cắt và biến nạp vào tế bào $E$.coli $c c d B$ (Invitrogen) là dòng tế bào đặc biệt dùng để nhân nuôi vector con thoi $\mathrm{pENTR} 3 \mathrm{C}$. Kiểm tra plasmid tái tổ hợp tạo thành bằng các enzym $K p n \mathrm{I}$ và $X h o I$ và đọc trình tự.

Tạo vector adenovirus tái tổ hợp mang gen chIL-6: Thực hiện quá trình đồng nhiễm 300 ng DNA khung adenovirus $p A d / C M V / V 5-D E S T$ và 150 ng DNA plasmid con thoi tái tổ hợp ( $p$ ENTR3C/chIL-6) nhờ enzyme Clonase II (phản ứng trên tổng $10 \mu \mathrm{l}$ ) trong tế bào E.coli DH5 $\alpha$ theo quy trình sử dụng kit virapower của hãng Invitrogen.

Lúc này, phần DNA của plasmid con thoi chứa gen $c h I L-6$ và phụ trợ sẽ được gắn vào khung $p A d / C M V / V 5-D E S T$ tạo nên plasmid tái tổ hợp qua 2 vị trí cánh tay trái và cánh tay phải.

Tạo adenovirus tái tổ hợp nhờ tế bào HEK293A: Trước tiên, plasmid pAd/CMV/V5DEST-chIL6 đã được cắt mở vòng bằng enzyme cắt giới hạn $P a c \mathrm{I}$, tinh sạch, thu được AdenochIL6-LITR/RITR mạch thẳng, tiến hành xâm nhiễm vào tế bào HEK293A.

Tế bào động vật dòng HEK293A được nuôi trong môi trường DMEM có bổ sung 10\%FBS, L-glutamine, kháng sinh, kháng nấm. Chuẩn bị lượng tế bào cần thiết đạt nồng độ $5 \times 10^{5} /$ giếng (bản 6 giếng), được nuôi sau 1 ngày, phủ khoảng $80 \%$ đáy giếng thì sẵn sàng cho việc xâm nhiễm. Xâm nhiễm $3 \mu \mathrm{g}$ DNA-Adeno-chIL6-LITR/RITR giếng nhờ bằng $3 \mu 1$ Lipofectamine ${ }^{\mathrm{TM}}$ 2000. Mẫu ĐC (-) DNA-Adeno-chIL6-LITR/RITR được thay bằng môi trường (chỉ nuôi HEK293A). Mẫu ĐC (+) DNA-Adeno-chIL6-LITR/RITR được thay bằng DNA-AdenoLITR/RITR (Adenovirus mạch thẳng chưa được gắn thêm gen ngoại lai). Đĩa nuôi cấy được ủ trong tủ ấm $37^{\circ} \mathrm{C}, 5 \% \mathrm{CO}_{2}$.

Tách chiết DNA tổng số tù huyễn dịch thu đượ: Để kiểm tra virus tái tổ hợp đã thực sự được tạo thành trong tế bào HEK293A chưa, sau khi rửa cặn tế bào bằng đệm $\mathrm{PBS} 3$ lần, tách chiết DNA tổng số từ tế bào thu được sau đó dùng cặp mồi đặc hiệu nhân đoạn gen chIL-6 có kích thước là 726 bp trong vector adenovirus tái tổ hợp. Dịch DNA tổng số bao gồm cả hệ gen của tế bào HEK293A và DNA của virus, sản phẩm được bảo quản $-20^{\circ} \mathrm{C}$. Sử dụng nguồn khuôn DNA được tách chiết nêu trên và cặp mồi đặc hiệu nhân đoạn gen chIL6 dài 726 bp.

Chuẩn độ adenovirus bằng phương plaque forming method: Bỏ hết tất cả môi trường ở các giếng tế bào 1 lớp nuôi cấy vi rút. Nhẹ nhàng đổ $2 \mathrm{ml}$ thạch DMEM $0,5 \%\left(44^{\circ} \mathrm{C}\right)$ lên bề mặt lớp tế bào bên dưới của mỗi giếng, kể cả tế bào đối chứng. Khi thạch đông lại, đưa khay nuôi cấy vào trong tủ ấm $37^{\circ} \mathrm{C}$, có $5 \% \mathrm{CO}_{2}$. Plaque được hình thành sau 6 ngày và tính toán số lượng plaque sau 6 ngày " úp mặt thạch". Dùng crytal violet để nhuộm mỗi giếng thạch, ủ tiếp ở tủ ấm $37^{\circ} \mathrm{C}$ trong $2-3$ giờ. Sau đó, hút hết chất nhuộm, lật ngược khay thạch, để nhìn rõ plaque rõ hơn từ phía đáy sẽ hiển thị là lỗ hổng trong suốt trên nền màu xanh tím. Mỗi một lỗ hổng đó được tính là 1 đơn vị plaque (PFU).

Tinh sạch adenovirus: Tế bào được thu hoạch khi thấy hiệu ứng gây nhiễm adenovirus vào tế bào và tế bào bắt đầu bong lên, giải phóng adenovirus từ tế bào bằng cách sử dụng đóng băng 
/ tan băng 3 chu kì, chúng tôi sử dụng bộ kit ibiPure TM adeno(Germany) để tinh sạch adenovirus thu nhận được. Sau khi tinh sạch, lưu trữ các mẫu adenovirus tinh khiết ở $-80^{\circ} \mathrm{C}$.

Kiểm tra múc độ biểu hiện gen chIL-6 trong tế bào động vật HEK293A: Để kiểm tra hiệu quả việc tạo adenovirus tái tổ hợp mang gen ChIL-6 khi và mức độ biểu hiện gen ChIL-6 trong tế bào HEK293A, bằng với kháng thể chIL-6 chuẩn (sử dụng Kit Chicken Interleukin 6 ELISA - Cusabio-USA) để định lượng cytokines interleukin 6 có trong huyết thanh hoặc dịch mô.

Tính toán: Kết quả (gọi là $\mathrm{S} / \mathrm{P}$, sample to positive ratio) được tính toán dựa trên thương số của chỉ số hấp phụ màu sắc của mẫu (so với đối chứng âm) với chỉ số hấp phụ màu sắc của đối chứng dương (so với đối chứng âm). Công thức tính toán:

$\mathrm{S} / \mathrm{P}=\frac{\mathrm{OD} \text { trung bình của mẫu }-\mathrm{OD} \text { trung bình của mẫu âm chuẩn }}{\mathrm{OD} \text { trung bình mẫu dương chuẩn - OD trung bình mẫu âm chuẩn }}$

(Ghi chú: Nếu $\mathrm{S} / \mathrm{P} \geq 0,5$ : mẫu được đánh giá dương tính, tức là có chứa hàm lượng cytokine cao hơn giá trị thấp nhất đo được là 15,63 pg/ml của bộ kit cung cấp bởi Cusabio Inc).

\section{KẾT QUẢ VÀ THẢO LUẬN}

\subsection{Tạo plasmid con thoi mang đoạn gen $\operatorname{chIL-6}$}

Để chuyển đoạn gen thu nhận được vào vector con thoi $p E N T R 3 C$, là vector trung gian chuyển gen vào vector adenovirus, chúng tôi thiết kế cặp mồi mới có gắn 2 enzyme cắt giới hạn $X h o \mathrm{I}, K p n \mathrm{I}$ và trình tự kozak cần thiết khi chuyển vào vector $p E N T R 3 C$ như sau:

chIL6FP-pENTR3C: TATCGGTACCGCCGCGATATGGCTAACTTCACCGA (KpnI).

chIL6RP-pENTR3C: TCAGCTCGAGGGCACTGAAACTCCTGGTCTTTTTC (XhoI).

Điện di sản phẩm khuếch đại đoạn gen đã được tách dòng từ công trình [9] bằng cặp mồi đặc hiệu mới thiết kế được thể hiện trên Hình 1 . Sản phẩm PCR sau khi được gắn vào vector tách dòng pUC57, plasmid $p U C 57 / C h I L 6$ và plasmid pENTR3C bằng các enzyme giới hạn Kpn I và $X h o \mathrm{I}($ Hình 2$)$. Kết quả cắt kiểm tra plasmid tái tổ hợp $p E N T R 3 C / c h I L 6$ tạo thành bằng các enzym KpnI và XhoI được thể hiện trên điện di đồ trên Hình 3.

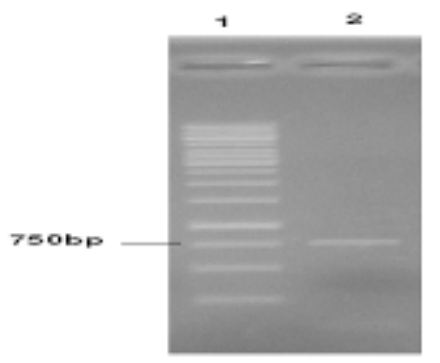

Hình 1. Điện di đồ sản phẩm PCR bằng cặp mồi đặc hiệu .

1: Marker 1kb DNA (Fermentas) 2: Sản phẩm PCR

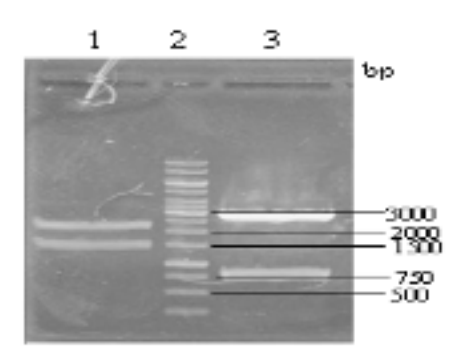

Hình 2. Điện di đồ sản phẩm cắt của pUC57/ChIL-6 và pENTR $3 C$ bằng $K p n I$ và $X h o \mathrm{I}$.

1: pENTR 3C ; 2: Marker $1 \mathrm{~kb}$ DNA (Fermentas) ; 3: pUC57/ChIL-6

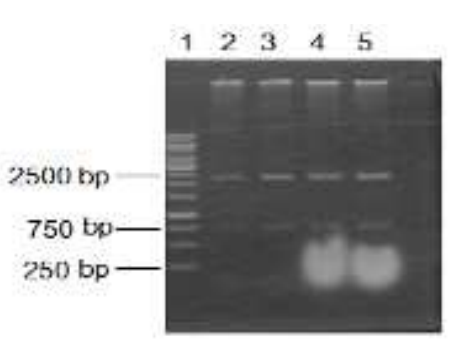

Hình 3. Điện di đồ sản phẩm cắt của plasmid pENTR/ChIL-6 bằng KpnI và XhoI.

1: Marker 1kb DNA (Fermentas)

4, 5: Sản phẩm cắt của $\mathrm{pENTR/ChIL-}$ 
Sau khi đọc trình tự plasmid tái tổ hợp và xử lí bằng phần mềm bioedit, kết quả cho thấy chúng tôi đã tạo thành công plasmid con thoi mang gen chIL-6. Plasmid này được sử dụng tiếp theo cho việc tạo vector adenovirus tái tổ hợp mang gen $c h I L-6$ qua quá trình đồng nhiễm.

\subsection{Kết quả tạo vector adenovirus tái tổ hợp mang gen $c h I L-6$}

Chỉ những tế bào đã thực sự mang plasmid tái tổ hợp pAd/CMV/V5-DEST/chIL-6 mới có khả năng sống được trong môi trường chọn lọc kháng sinh Ampicillin, là kháng sinh chọn lọc của vector $p A d / C M V-V 5$. Để khẳng định điều đó, kiểm tra kết quả đồng nhiễm bằng $\mathrm{PCR}$ và tiến hành giải trình tự plasmid thu nhận được bằng cặp mồi phát hiện hệ gen Adenovirus:

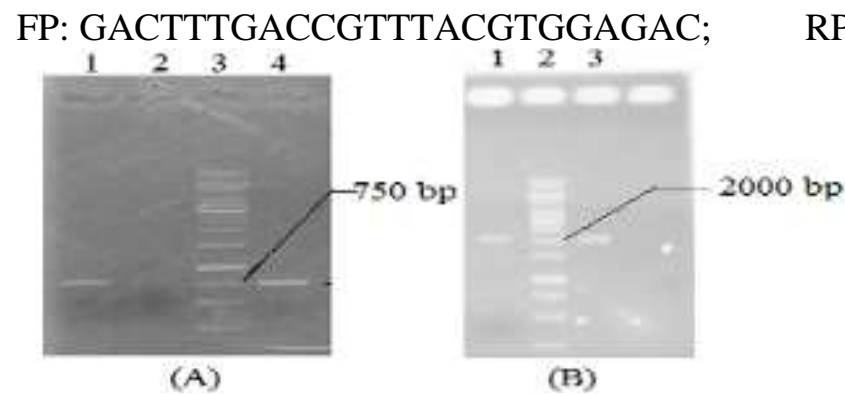

Hình 4. Điện di đồ kiểm tra hiệu quả tạo vector adenovirus tái tổ hợp.

(A): 1,4: Sản phẩm PCR sử dụng cặp mồi khuếch đại đoạn gen $c h I L-6$ với khuôn là plasmid được tách từ các khuẩn lạc $E$. coli sau đồng nhiễm; 2: Sản phẩm PCR với khuôn pAd/CMV/V5-DEST gốc. 3: Marker DNA $1 \mathrm{~kb}$ plus Fermentas.

(B): Sản phẩm PCR với cặp mồi khuếch đại đoạn gen phát hiện hệ gen adenovirus; 1,3 : sản phẩm PCR;

RP: CTTTTATAGGTGTAAACCTTAAAC.

Kêt quả giải trình tự và khuêtch đại gen cho thây chúng tôi đã có được vector adenovirus tái tổ hợp mang đoạn gen chIL-6 (Hình 4); Sau đó, plasmid pAd/CMV/V5-DEST-chIL6 được cắt mở vòng bằng enzyme cắt giới hạn $\mathrm{PacI}$ (Hình 5) sẵn sàng cho việc xâm nhiễm vào tế bào HEK293A.

\subsection{Kết quả tạo adenovirus tái tổ hợp nhờ tế bào HEK293A}

Một ngày sau xâm nhiễm, loại bỏ hoàn toàn môi trường, DNA- Adeno-chIL6-LITR/RITR, Lipofectamine $^{\mathrm{TM}} 2000$ dư bằng môi trường mới. Trong suốt quá trình nuôi cấy, quan sát sự thay đổi hình thái tế bào thường xuyên, bổ sung môi trường mới khi môi trường chuyển màu. Một số hình ành nuôi cấy tế bào HEK293 bị virus phá hủy, chụp trên kính hiển vi soi ngược được thể hiện trên Hình 6. 


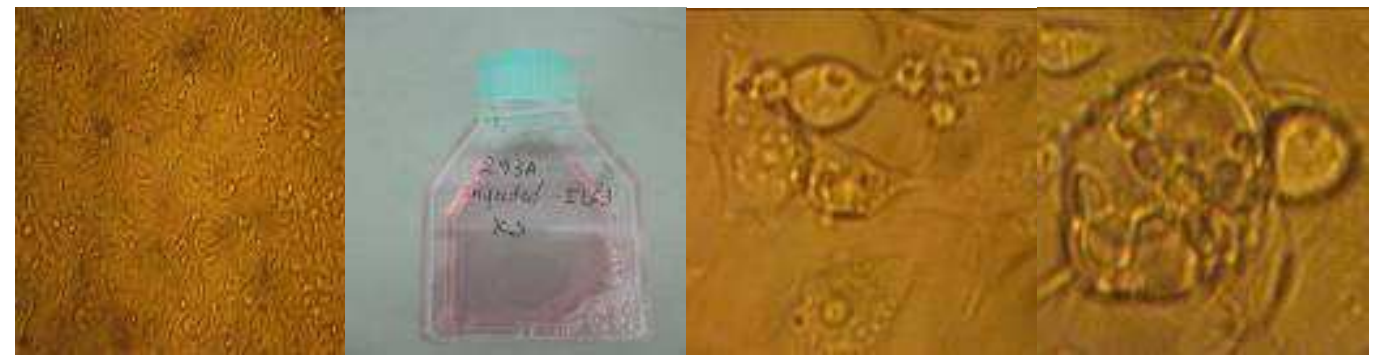

Hình 6. Hình ảnh nuôi cấy tế bào HEK293 bị virus phá hủy, chụp trên kính hiển vi soi ngược.

Sau 2 ngày, quan sát thấy tại các giếng xâm nhiễm, tế bào bắt đầu chết và nổi lên bề mặt nhiều hơn, giếng ĐC(-) không xâm nhiễm mịn hơn. Quan sát các tế bào HEK293A sau 4 ngày, tại các giếng đối chứng âm, tế bào bắt đầu chết khá nhiều do già và không đủ chỗ bám, từng tế bào nổi lên bế mặt riêng rẽ, tại giếng đối chứng dương và giếng xâm nhiễm tế bào chết nhiều thành từng cựm. Sau 6 ngày xâm nhiễm, ở giếng nuôi mẫu xâm nhiễm, các tế bào về sản xuất adenovirus tế bào chết nổi lên từng mảng, một số khu vực trong đĩa nuôi cấy tạo thành bợn, do đó nhìn thấy được rõ ràng. Thu nhận adenovirus sau 6 ngày xâm nhiễm vào tể bào HEK293A bằng phương pháp đông/tan. Chuyển dịch nước nổi có chứa các hạt vius vào từng ống $1 \mathrm{ml}$ dịch, tạm lưu giữ mẫu ở $-80^{\circ} \mathrm{C}$.

Tiếp truyền $0,1 \mathrm{ml}$ mẫu lưu giữ ở trên vào đĩa nuôi cấy đường kính $10 \mathrm{~cm}$, nhằm tăng sinh adenovirus tái tổ hợp. Sau quá trình tiếp truyền, tiếp tục thực hiện phản ứng khuếch đại gen với template là DNA tổng số tách từ mẫu tiếp truyền lượng lớn $\mathrm{pAd} / \mathrm{CMV} / \mathrm{V} 5-\mathrm{DEST}$-chIL6 với cặp mồi khuếch đại đoạn gen $c h I L-6$ dài 726 bp và với cặp mồi phát hiện đoạn gen Adenovirus dài $2 \mathrm{~kb}$.

\subsection{Kiểm tra hiệu quả xâm nhiễm plasmid tái tổ hợp pAd/CMV/V5-DEST/chIL-6 bằng PCR}

Để kiểm tra virus tái tổ hợp đã thực sự được tạo thành trong tế bào HEK293A chưa, sau khi rửa cặn tế bào bằng đệm PBS 3 lần, tiến hành tách chiết DNA tổng số (bao gồm cả hệ gen của tế bào HEK293A và DNA của virus) từ các mẫu nuôi cấy. Dưới đây là kết quả khuếch đại gen sử dụng cặp mồi đặc hiệu phát hiện virus và cặp mồi nhân đoạn gen $c h I L-6$ dài 726 bp.

Kết quả điện di trên Hình 7(A) cho thấy xuất hiện băng sản phẩm PCR kích thước khoảng 2000 bp trong các mẫu xâm nhiễm, ở cả sản phẩm PCR với khuôn là DNA tổng số tách từ mẫu đối chứng (xâm nhiễm $\mathrm{pAd} / \mathrm{CMV} / \mathrm{V} 5-\mathrm{DEST}$ gốc và mẫu sản phẩm PCR với khuôn là DNA tổng số tách từ mẫu xâm nhiễm $\mathrm{pAd} / \mathrm{CMV} / \mathrm{V} 5-\mathrm{DEST}$-chIL6. Kết quả này phù hợp với kích thước của đoạn gen phát hiện hệ gen adenovirus. Kết quả điện di trên Hình 7(B) cho băng sản phẩm PCR phù hợp với kích thước của đoạn gen $c h I L-6$ trên đường chạy 1,3 là sản phẩm $\mathrm{PCR}$ với khuôn là DNA tổng số tách từ mẫu có xâm nhiễm pAd/CMV/V5-DEST-chIL6 và sản phẩm PCR với khuôn là DNA tổng số tách từ mẫu tiếp truyền lượng lớn. Điều đó, cho thấy đã có sự tồn tại của hệ gen adenovirus và đoạn gen $c h I L-6$ trong các mẫu xâm nhiễm và được nhân qua các thế hệ tại các mẫu tiếp truyền. 

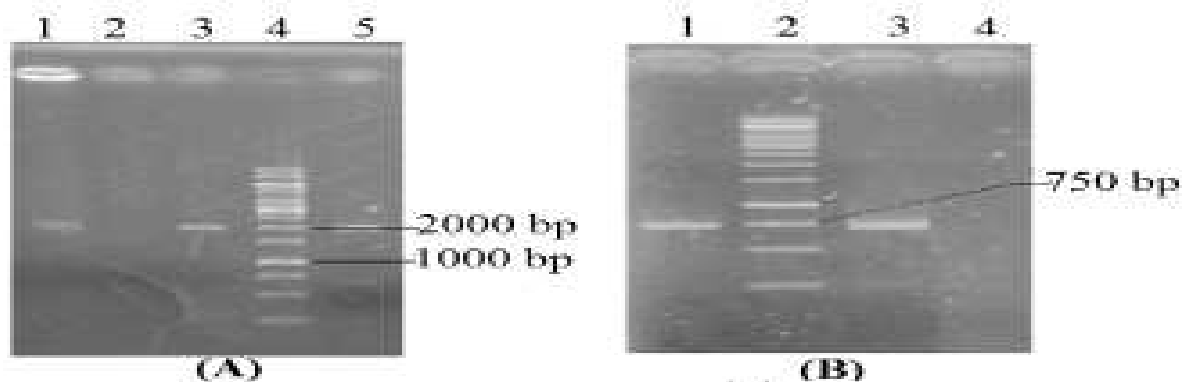

Hình 7. Kết quả kiểm tra hiệu quả xâm nhiễm bằng PCR.

(A): PCR sử dụng cặp mồi nhân đoạn gen gen phát hiện adenovirus; 1: Sản phẩm PCR với khuôn là DNA tổng số tách từ mẫu đối chứng (xâm nhiễm pAd/CMV/V5-DEST gốc); 2: Sản phẩm PCR với khuôn là

DNA tổng số tách từ mẫu đối chứng chỉ nuôi tế bào HEK293A; 3: Sản phẩm PCR với khuôn là DNA tổng số tách từ mẫu xâm nhiê̂m pAd/CMV/V5-DEST-chIL6;4: Marker DNA 1kb plus (fermentas); 5: Sản phẩm PCR với khuôn là DNA tổng số tách từ mẫu tiếp truyền lượng lớn.

(B): PCR sử dụng cặp mồi nhân đoạn gen chIL-6; 1: Sản phẩm PCR với khuôn là DNA tổng số tách từ mẫu có xâm nhiễm pAd/CMV/V5-DEST-chIL6; Giếng 2: Marker DNA 1kb plus (fermentas);

3: Sản phẩm PCR với khuôn là DNA tổng số tách từ mẫu tiếp truyền lượng lớn; 4: Sản phẩm PCR với khuôn là DNA tổng số tách từ mẫu đối chứng âm (xâm nhiễm pAd/CMV/V5-DEST gốc).

\subsection{Kiểm tra hiệu quả xâm nhiễm plasmid tái tổ hợp pAd/CMV/V5-DEST/chIL-6 bằng ELISA}

Để kiểm tra hiệu quả việc tạo adenovirus tái tổ hợp mang gen ChIL6 bằng kháng thể chIL6 chuẩn (sử dụng Kit Chicken Interleukin 6 ELISA - Cusabio-USA) (Hình 8).
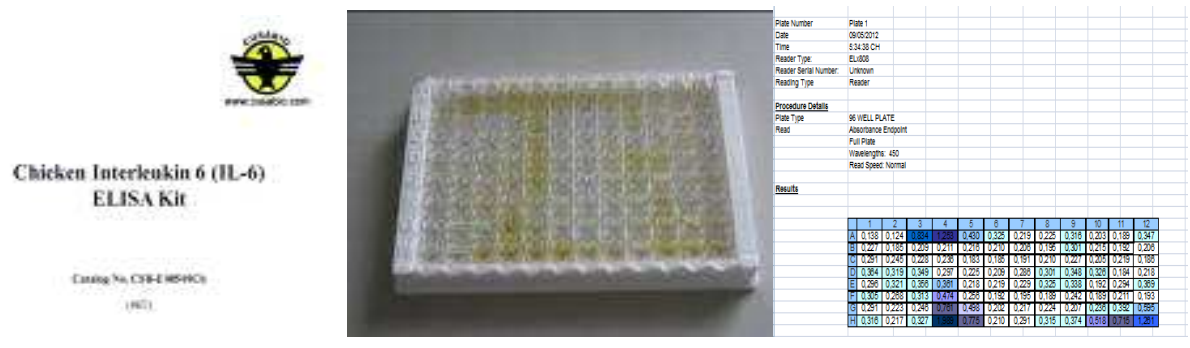

Hình 8. Một số hình ảnh và kết quả ELISA.

Kết quả cho thấy mẫu nuôi adenovirus xâm nhiễm plasmid tái tổ hợp cho kết quả OD $(0,316)$ cao hơn hẳn so với mẫu đối chứng dương $(0,225)$ và mẫu âm chuẩn $(0,135)$. Tính toán kết quả theo công thức $\mathrm{s} / \mathrm{p}>0,5$, kết quả được coi là có ý nghĩa và như vậy, từ các kết quả trên cho phép chúng tôi kết luận có thể hệ gen adenovirus tái tổ hợp với gen chIL6 đã được tạo ra và nhân lên lượng lớn trong các thế hệ tế bào HEK293A.

\subsection{Kết quả xác định mật độ adenovirus tái tổ hợp bằng "plaque forming method"}




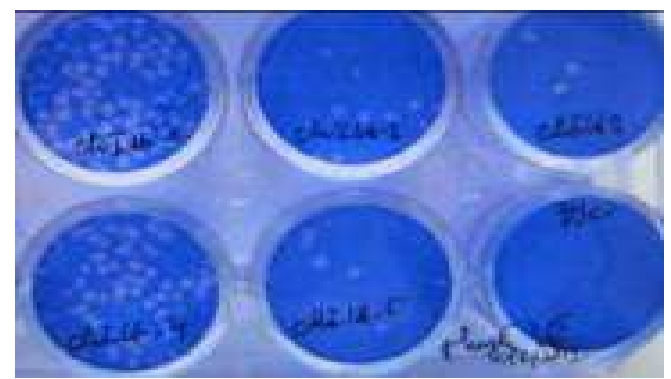

Hình 9. Hình ảnh xác định mật độ adenovirus tái tổ hợp bằng " Plaque forming method".

Sử dụng phương pháp tính trên phần phương pháp. Trong đó, $\mathrm{d}$ là hệ số pha loãng từ mẫu gốc; $\mathrm{V}$ là dung lượng $(\mathrm{ml})$ chứa vi rút cấy vào mỗi giếng (volume). Số plaque trung bình $=3$ (Hình 9) ở độ pha loãng $10^{-7} ; \mathrm{d}=0,000001 ; \mathrm{V}=0,2 \mathrm{ml}$. PFU được tính như sau:

$$
\text { 3: }(0,000001 \times 0,2)=1,5 \times 10^{7} \mathrm{PFU} / \mathrm{ml}
$$

vậy nồng độ gốc của mẫu adenovirus tái tổ hợp là $1,5 \times 10^{7} \mathrm{PFU} / \mathrm{ml}$.

Sản xuất và khuếch đại lượng lớn của adenovirus trong các dòng tế bào sản xuất từ những tế bào như HEK293, adenovirus được giải phóng bởi chu trình đóng băng / tan băng. Hỗn hợp adenovirus thu được sẽ chứa tế bào adenovirus và các thành phần khác có thể ảnh hưởng xấu đến việc tải nạp tế bào trong cơ thể và trong ống nghiệm. Chúng tôi sử dụng ibiPure ${ }^{\mathrm{TM}}$ adeno Adenovirus: Đây là kit tinh sạch adenovirus đáng tin cậy được sản xuất tại Đức, với tỉ lệ thu hồi cao. Adenovirus sau khi tinh sạch nồng độ đạt tới $5 \times 10^{9} \mathrm{pfu} / \mathrm{ml}$.

\section{BÀN LUẬN}

Vector adenovirus được coi là nguồn công cụ để dẫn truyền gen cytokine linh hoạt, có hiệu quả, trước hết là vì adenovirus vector tạo nên adenovirus thiểu năng trong tế bào HEK293A, nên khả năng sản sinh và giới thiệu cytokine trong cơ thể của chúng được coi là hoàn thiện $[5$, 7]. Trong các hệ thống vector dẫn truyền gen ngoại lai làm chế phẩm thế hệ mới, hệ thống vector adenovirus được đặc biệt chú ý nghiên cứu và sử dụng, do adenovirus có kích thước linh hoạt, có đặc tính thích ứng đa tế bào vật chủ, vô hại với nhiều loài, nhân lên mạnh khi nuôi cấy trên tế bào tổ chức để sản xuất vaccine (in vitro), cho hàm lượng virus nhiều, và khi vào đối tượng (in vivo) cũng có khả năng ổn định nhân lên duy trì kháng nguyên nhưng không gây hại vật chủ $[5$, $6,10]$.

Tháng 9 năm 2014, WHO và Mỹ lựa chọn làm vaccine ngăn chặn sự lây lan của dịch Ebola là vaccine Ebola dựa trên công nghệ adenovirus. Vaccine được sử dụng trực tiếp trên đội ngũ bác sỹ, y tá, nhân viên y tế tiếp xúc và có nguy cơ lây nhiễm Ebola cao và các tình nguyện viên. Hãng dược phẩm Glaxo Smith Kline (GSK) phối hợp với Viện Dị ứng và bệnh truyền nhiễm (NIAID) đã nhận trách nhiệm sản xuất 10.000 liều vaccine. Vaccine sử dụng vector dẫn truyền là adenovirus serotype 3 có nguồn gốc phân lập từ tinh tinh (chAd3) đã cắt bỏ gen $\mathrm{E} 1$ và $\mathrm{E} 3$ và thay thế vào đó là gen mã hóa cho một protein bề mặt của hai chủng Ebola khác nhau. Kết quả không có người nào có phản ứng phụ và tất cả đều sản sinh kháng thể chống lại vi rút Ebola. Các nhà khoa học của Viện Sức khỏe quốc gia $\mathrm{Mỹ}(\mathrm{NIH})$ cho biết, kết quả đạt được "hứa hẹn" khả quan [11].

Trên thế giới, nghiên cứu hệ thống vector adenovirus và định hướng ứng dụng đa dạng đã được tiến hành từ lâu, và nhiều loại vaccine và chế phẩm sinh học trên nền adenovirus vector đã được ứng dụng cho động vật và người $[12,13]$. Adenovirus vector đã được tận dụng như là một 
lợi thế công nghệ đưa cytokine vào gia cầm, ví dụ với interferon gamma (IFN-gamma) hay với interleukin-2 và nhiều loại hình cytokine khác $[1,6,13]$.Cho đến nay, tại Việt Nam, phòng thí nghiệm của chúng tôi là cơ sở đầu tiên nghiên cứu một cách có hệ thống việc nghiên cứu cytokine và adenovirus làm vector, tạo chế phẩm tái tổ hợp để tận dụng hoạt động miễn dịch mà vector này đem lại.

\section{KẾT LUẬN}

Bằng các kĩ thuật sinh học phân tử, chúng tôi đã tạo ra được vector tái tổ hợp $p A d / C M V$ V5-chIL6. Adenovirus tái tổ hợp mang đoạn gen chIL-6 được hình thành sau quá trình xâm nhiễm plasmid vector $p A d / C M V$-V5-chIL6 vào tế bào HEK293A. Giống adenovirus tái tổ hợp sơ cấp có mật độ $1,5 \times 10^{7} \mathrm{PFU} / \mathrm{ml}$ này sẽ cho ta các thế hệ adenovirus tái tổ hợp mới khi tiếp truyền trên tế bào HEK 293A. Hiệu quả của quá trình tạo adenovirus đã được thử nghiệm bằng phản ứng ELISA trực tiếp tóm bắt kháng nguyên nhờ kháng thể interleukin 6 chuẩn của gà, cung cấp bởi hãng Cusabio (USA). Adenovirus tinh sạch thu nhận được có mật độ tương đối cao. Với các kết quả đã đạt được, bước tiếp theo chúng tôi sẽ kiểm tra an toàn của adenovirus tái tổ hợp mang gen $c h I L-6$, tối ưu hóa liều dùng và thử nghiệm in vivo trên đàn gà quy mô nhỏ.

Lòi cảm ơn. Nhóm nghiên cứu chân thành cảm ơn chương trình trọng điểm phát triển và ứng dụng Công nghệ Sinh học - Bộ nông nghiệp và phát triển nông thôn đã giúp đỡ chúng tôi về kinh phí để hoàn thành nội dung này.

\section{TÀI LIỆU THAM KHẢO}

1. Jenkins K. A., Hilton L. S., Kimpton W. G., Bean AG., Lowenthal J. - Cytokines as adjuvants for avian vaccines, Immunol, Cell Biol, 82 (6) (2004) 638-643.

2. Giansanti F., Giardi M. F., and Botti D. - Avian Cytokines - An Overview. Current Pharmaceutical Design 12 (24) (2006) 3083-3099.

3. Schneider K., Klaas R., Kaspers B., Staeheli P. - Chicken interleukin-6. cDNA structure and biological properties, Eur. J. Biochem, 268 (15) (2001) 4200-4206.

4. Tatsis N., Ertl H. C. - Adenoviruses as vaccine vectors, Mol. Ther. 10 (4) (2004) 6166296.

5. Franceschi R. T. and Ge C. - Gene delivery by adenoviruses, Methods Mol, Biol, 455 (2008) 137-147.

6. Curiel D. T., Douglas J. T. - Adenoviral vectors for gene therapy, Academic Press, USA, 2002, pp 677.

7. Lê Thanh Hòa - Công nghệ Adenovirus và nguyên lí tạo vector tái tổ hợp: sách chuyên khảo, Nhà xuất bản Khoa học tự nhiên và công nghệ, Hà Nội, 2010, pp. 227.

8. http://tools.invitrogen.com/content/sfs/manuals/virapower_adenoviral_system man.

9. Vũ Thị Thu Huyền, Nguyễn Thị Kim Cúc, Trần Thị Kim Dung, Lê Thị Hồng Minh, Phạm Việt Cường - Tách dòng và thiết kế vector trung gian mang gen IL-6 của gà Việt Nam, Tạp chí Sinh học 35 (1) (2013) 105-109.

10. Impler J. L. - Adenovirus vectors as recombinant viral vaccines, Vaccine 13 (13) (1995) 1143-1151.

11. http://www.who.int/medicines/emp ebola q_as/en/ 
12. Souza AP., Haut L., Reyes-Sandoval A., Pinto A. R. - Recombinant viruses as vaccines against viral diseases, Braz. J. Med. Biol. Res. 38 (4) (2005) 509-522.

13. Tayal V., Kalra B. S. - Cytokines and anti-cytokines as therapeutics, Europ. J. Pharm. 579 (2008) 1-12.

\section{ABSTRACT \\ GENERATION OF RECOMBINANT ADENOVIRUSES CARRYING THE GENE CODING FOR INTERLEUKIN 6 OF CHICKEN}

Vu Thi Thu Huyen ${ }^{1, *}$, Le Thi Hong Minh ${ }^{1}$, Nguyen Thi Kim Cuc ${ }^{1}$, Vi Thi Quyen ${ }^{1}$, Nguyen Mai Anh ${ }^{1}$, Le Thanh Hoa ${ }^{2}$, Pham Viet Cuong ${ }^{1}$

${ }^{1}$ Institute of Marine Biochemistry, VAST, 18 Hoang Quoc Viet, Cau Giay, Hanoi

${ }^{2}$ Institute of Biotechnology, VAST, 18 Hoang Quoc Viet, Cau Giay, Hanoi

*Email: Huyenvuibt@gmail.com

In our previous study in 2013, we had cloned Vietnamese chicken interleukin 6 gene. In this study, we describe the creation of an recombinant adenovirus containing chIL-6 as an immune stimulation product for poutry.

ChIL-6 gene was amplified total RNA extracted from the spleen of Vietnamese chicken cell by RT-PCR. Then ChIL-6 gene was cloned into the shuttle vector pENTR3C that carried attL1 and attL2 sites for site-specific recombination of the entry clone with gateway destination vector to generate a recombinant plasmid $p A d / C M V$-V5-chIL6. $p A d / C M V$-V5-chIL6 was exposed by PacI enzyme, the purpose of PacI digestion is to liberate the two ITRs (left and right) of adenoviral genome.

Finally, the recombinanted adenovirus $p A d / C M V$-V5-chIL6 was transfected into HEK293A cells for packaging and amplification. ChIL-6 expression in transfected HEK293A cells could be observed at 48 - 72 hours post. Adenovirus and ChIL-6 gene was detected in infected HEK293A cells by using PCR. ChIL-6 protein was detemined by ELISA with chicken Interleukin 6 antibody (Cusabio, USA). The titer of recombinant adenovirus is $5 \times 10^{9} \mathrm{PFU} / \mathrm{ml}$ after purification by using ibiPure ${ }^{\mathrm{TM}}$ adeno kit (Germany).

Keywords: adenovirus, ChIL-6, cytokine, HEK293A, pAd/CMV/V5-DEST, pENTR3C. 